\title{
En forskningsetisk gråsone
}

\author{
Det er formålet med et forskningsprosjekt som bestemmer om det skal behandles i de regionale komiteer \\ for forskningsetikk - ikke metoden. Likevel opplever vi gjentatte ganger at prosjekter som er i overensstem- \\ melse med veilederen for vurdering av forskningsprosjekter, blir avvist på grunn av formålet. Prosjektene \\ er i en forskningsetisk gråsone.
}

I 2009 ga Den nasjonale etiske komité for medisinsk og helsefaglig forskning (NEM) ut en veileder for vurderinger av forskningsprosjekter der det anvendes kvalitative metoder (1). Prosjekter som dreier seg om medisinsk og helsefaglig forskning på mennesker, humant biologisk materiale eller helseopplysninger, skal legges frem for de regionale komiteer for forskningsetikk (REK). Medisinsk og helsefaglig forskning blir i helseforskningsloven $\S 4$ a definert som «virksomhet som utføres med vitenskapelig metodikk for å skaffe til veie ny kunnskap om helse og sykdom» (2). Det er altså formålet med prosjektet som avgjør om det skal legges frem for de regionale komiteer for forskningsetikk eller ikke.

Veilederen åpner opp for en bred forståelse av slik forskning (1). Vi har likevel opplevd at fem av våre prosjekter, alle $\mathrm{i}$ overensstemmelse med veilederens formuleringer, er blitt avvist på grunn av formålet.

\section{Visjonen om én postkasse}

Helseforskningsloven av 2009 skulle bidra til å forenkle prosedyrene om forhåndsgodkjenning av forskningsprosjekter om helse og sykdom (3). Tidligere hadde forskerne måttet forholde seg til to godkjenningsinstanser, de regionale komiteer for forskningsetikk og Norsk samfunnsvitenskapelig datatjeneste (NSD). De regionale komiteene hadde som hovedoppgave å vurdere de etiske, medisinske, helsefaglige og vitenskapelige sidene ved prosjektene, Norsk samfunnsvitenskapelig datatjeneste de personvernmessige. Sistnevnte var da som nå et rådgivings- og serviceorgan for å vurdere prosjektene ut fra personopplysningsloven og helseregisterloven.

Med helseforskningsloven fikk de regionale komiteer for forskningsetikk et utvidet myndighetsområde. De skulle nå også vurdere de personvernmessige sidene ved prosjektene: Var forskningen organisert og utøvd på en forsvarlig måte, ble det vist respekt for forskningsdeltakernes menneskerettigheter og menneskeverd, og ble hensynet til deltakernes velferd og integritet ivaretatt?

Da vi skulle sende inn søknader om forhåndsgodkjenninger av forskningsprosjekter, forholdt vi oss til helseforskningsloven og veilederen. Prosjektene våre beskriver og analyserer hvordan «livet på helseinstitusjoner» (1) utfolder seg og hvordan dette former sykdomserfaringer og fagutøvelse (4) gjennom observasjon (5). Vi fikk imidlertid beskjed om at de regionale komiteer for forskningsetikk ikke skal vurdere denne typen prosjekter.

I to av tilfellene stanset vårt forhold til komiteene her, og vi kunne sende inn søknad om forhåndsgodkjenning til Norsk samfunnsvitenskapelig datatjeneste. I to andre tilfeller måtte vi tydeliggjøre formålet med prosjektene, metoder og samtykkeskjema før endelig avslag ble gjort. I det siste tilfellet måtte vi $i$ etterkant gjennom omfattende saksbehandlingsrunder også i Norsk samfunnsvitenskapelig datatjeneste. Siden det ikke alltid er praktisk mulig å innhente samtykke fra alle som er innom en avdeling, måtte vi søke om dispensasjon fra taushetsplikten - en myndighet som ble delegert til de regionale komiteene i 2009. Norsk samfunnsvitenskapelig datatjeneste henviste oss tilbake dit, og nye søknadspapirer måtte fylles ut.

\section{Forhåndsgodkjenning = juridiske formalia?}

At prosjektene ble definert utenfor helseforskningsloven, førte til nye, ressurskrevende saksbehandlingsrunder. I ett av prosjektene, der forskningen var samtykkebasert og følgelig ikke trengte dispensasjon fra taushetsplikten, ble det av enkelte informanter reist tvil om forhåndsgodkjenningen. Så lenge vi ikke hadde godkjenningsbrev fra de regionale komiteer for forskningsetikk, ville de ikke la seg observere. I et av de andre prosjektene ble premissene for forsvarlighet praktisert forskjellig i de regionale komiteene og Norsk samfunnsvitenskapelig datatjeneste. Komiteen hadde vært tilbakeholden med å la oss intervjue innlagte pasienter, mens personvernombudet ga tillatelse til dette, selv om de på forhånd var kjent med komiteens vurdering.

Selv om prosjektene var på juridisk sikker grunn, oppsto det ubehagelige situasjoner. De regionale komiteene har bedre kjennskap til sårbarheten til informantgruppen i prosjektet, men vi måtte likevel følge føringer gitt av Norsk samfunnsvitenskapelig datatjeneste. I praksis måtte vi forholde oss til begge godkjenningsinstansene. Vi var i en forskningsetisk gråsone.

\section{Hvordan gjøre gråsonen mindre?}

Det å bli definert utenfor mandatet til helseforskningsloven, endrer ikke de etiske prinsippene for forskning på mennesker. Pro- sjektene er fremdeles regulert, men er premissene for regulering riktige? Bør ikke alle prosjekter som involverer mennesker, få en etisk vurdering? Hvis det er ønskelig med én postkasse, så hvorfor ikke etablere et system der alle prosjekter med forsøkspersoner sendes inn gjennom én portal i regi av de nasjonale forskningsetiske komiteer? Prosjekter kan deretter fordeles til de respektive komiteer for behandling.

Dersom dette ikke er ønskelig, bør de forskningsetiske komiteene tolke helseforskningslovens mandat ut fra en bred forståelse av sykdom og helse. Når prosjektene vurderes enkeltvis, kan det se ut som om det er en strengere forståelse av sykdom og helse som kommer til uttrykk enn i veilederen.

\section{Geir Lorem}

Aud Obstfelder

aud.obstfelder@uit.no

Institutt for helse- og omsorgsfag

Det helsevitenskapelige fakultet

Universitetet i Tromsø

Geir Lorem (f. 1969) er dr.art., førsteamanuensis ved Institutt for helse og omsorgsfag, Universitetet i Troms $\varnothing$, og medlem av Den nasjonale komité for medisin og helsefag (NEM). Forfatter har fylt ut ICMJE-skjemaet og oppgir ingen interessekonflikter.

Aud Obstfelder (f. 1965) er dr.polit. og førsteamanuensis ved Institutt for helse og omsorgsfag, Universitetet i Troms $\varnothing$.

Forfatter har fylt ut ICMJE-skjemaet og oppgir ingen interessekonflikter.

\section{Litteratur}

1. Veiledning for kvalitativ forskning. www.etikkom.no/no/Aktuelt/Aktuelt/Nyheter/ 2010/Veiledning-for-kvalitativ-forskning/ (14.5.2012).

2. Lov om medisinsk og helsefaglig forskning (helseforskningsloven). Nr. 442008. http://www.lovdata.no/all/hl-20080620-044.html (20.3.2012)

3. Nylenna M, Simonsen S. Helseforskningsloven. Tidsskr Nor Legeforen 2009; 129: 1320.

4. Hilden PK, Middelthon A-L. Kvalitative metoder i medisinsk forskning - et etnografisk perspektiv Tidsskr Nor Lægeforen 2002; 122: 2473-6.

5. Mays N, Pope C. Qualitative research: observational methods in health care settings. BMJ 1995; 311: $182-4$. 